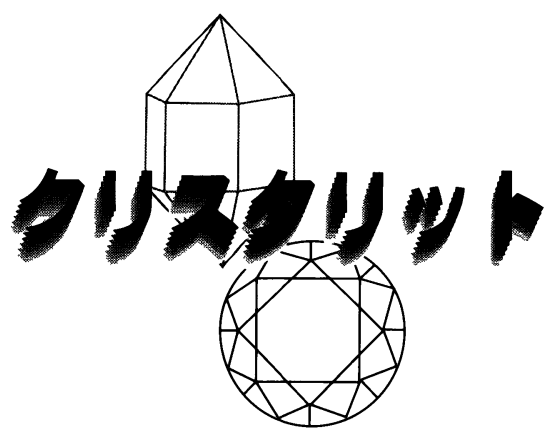

共鳴 X 線散乱

\section{Resonant X-ray Scattering}

入射 $\mathrm{X}$ 線のエネルギーが, 物質中構成原子 (イオン)の 吸収端エネルギーに近いとき, 散乱断面積が極端に大きく なるような散乱現象が存在する。この散乱は, 励起状態と してある寿命をもった共鳴状態を経て起きるため, 共鳴 X 線散乱と呼ばれる。例えば, $3 d$ 遷移金属イオンの場合, $1 s$ の内款電子を $4 p$ の非占有準位に励起する $K$ 吸収端は数 $\mathrm{keV}$ のエネルギーであり, 入射エネルギーをこのエネルギ 一に合わせることにより共鳴 X 線散乱が起こる.このと きの励起状態は， $1 s$ にホールができ $4 p$ に励起電子が存在 する状態である。このような共鳴状態を経ることにより， ターゲットとなる原子の散乱因子には, 通常のトムソン原 子散乱因子・以外に異常分散項と呼ばれる複素数が付け加 わる。

(東北大学:大学院理学研究科 村上洋一)

\section{極限条件 Extreme Condition}

ある環境下に物質をおいて物性測定を行う場合，一般に その測定量は環境を表すパラメー夕の関数となる.よくコ ントロールできるパラメータとして温度・磁場・電場・ 圧力などがあるが, 極限条件とはこ机らのパラメータがわ れわれの生活環境におけるものから著しく離れていると きの状態をさし，極限環境とも呼ばれる，極限条件下では 物質のもつ本質的な特性が顕わに現れる場合があるため， 物性実験ではこれらのパラメー夕を大きく変えた測定を よく行う. 最近では，これらの極限条件を複数組み合わせ ることにより，より本質的な物性を探る試みが多く行われ るようになっている.

(東北大学大学院理学研究科 村 上.洋 $\cdots$ )

\section{非弾性 X 線散乱 Inelastic X-ray Scattering}

入射された $\mathrm{X}$ 線と物質との相互作用により，入射 $\mathrm{X}$ 線 のエネルギーとは違ったエネルギーをもつX 線が散乱さ れる場合があり, 非弾性 X線散乱と呼ばれる.コンプトン 散乱はその典型例である. 最近では, 物質とやり取りする エネルギーがより小さな散乱も観測できるようになって
きた. 固体内でのプラズモンや数 $\mathrm{eV}$ オーダーのバンド間 泑起・電荷移動励起はもちろん, $\mathrm{meV}$ オーダーの格子振 動までもが観測可能となってきている.

\section{(東北大学大学院理学研究科 村上洋一) \\ PCR \\ Polymerase Chain Reaction}

Polymerase Chain Reactionの略称で, 目的とする特定 の DNA 領域を増幅する手法. まず, (1)高温にすると 2 本 鎖DNA が1本鎖へ解離する. (2)徐々に温度を下げると目 的とする DNA 領域の両末端と相補的塩基配列をもつプラ イマーが優先的に 1 本鎖 DNA に結合する. (3) 4 種類のデ オキシリボヌクレオシド三リン酸と DNA 合成酵素がプラ イマーを起点に相補鎖を合成していく. (4)再び温度を上げ ると合成された鎖がまた 1 本鎖へ解離する. 高温で機能を 発現する好温菌由来の DNA 合成酵素を利用することによ り，温度上下のサイクルを繰り返すだけで DNA 合成の連 鎖反心が起こり，数時間で 10 億倍以上に増幅させること ができる，微量のDNA から容易に増幅させることがで き, 遺伝子技術を駆使する最新医学, 分子生物学には必須 の技術であるばかりでなく、臨床医学の DNA 診断, 法医 学のDNA 人物鑑定など, 多方面に活用されている.

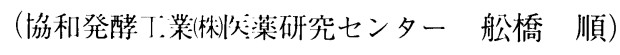

\section{示差走査熱量計}

\section{Differential Scanning Calorimeter}

示差走查熱量計 (DSC) は, 試料とその溶媒をそれぞれ 温度可変炉に入れ，その温度を一走速度で上昇もしくは下 降させながら, 画者が温度差を生じないようにヒーター電 流を制御し、試料に供給するその過剩な熱量を定量的に測 定する装置である. 蛋白質の場合, 变性状態と天然状態で は熱容量に差があり，両状態間の熱容量差を測定すること ができる.また，熱変性には熱吸収反応が伴い，その急激 な熱容量変化から, 変性温度や変性のエンタルピー变化な ど、熱変性に伴う熱力学的パラメータを直接測定すること ができる. 創薬の現場では, 薬剤の熱安定性測定や品質試 験などにも活躍している. 最近, 蛋白質測定に有効な微少 な熱容量変化をも感知できる高感度の断熱型DSC が普及 してきた

(協和発酵工業㑣矢薬研究センター 舩橋順)

\section{水和構造 \\ Hydration Structure}

蛋白質の周囲を覆う水分子 (水和水) の構造を水和構造 という，液体窒素温度下の結晶構造解析技術の向上によ り、動きやすい水分子の位置同定が可能になった。迫ら は数種の蛋白質について, 高分解能で低温構造解析するこ とにより, 水和水と蚠白質表面の極性原子団 (酸素, 窒素 
原子) が水素結合を介してクラスターを形成し，それらの クラスターが巨大なネットワーク構造を作っていること を明らかにした，そのネットワーク構造は, 蛋白質の機能 発現だけでなく, 立体構造形成にも重要であると考えら れている.

\section{(協和発酵工業(侏医薬研究センター 舩橋 順) \\ POP Family \\ Prolyl Oligopeptidase Family}

プロリルオリゴペプチダーゼファミリーとは, プロリ ルオリゴペプチダーゼ, ジペプチジルペプチダーゼ IV, ア シルアミノアシルペプチダーゼ, オリゴペプチダーゼ B な どが含まれるセリンプロテアーゼ活性をもつ酵素群であ る. 本ファミリーに属する酵素は, 基質として蛋白質では なくペプチド，それも 30 アミノ酸残基以下のものにしか 作用しない. 本ファミリーにおけるアミノ酸配列の特徵と して, $\mathrm{N}$ 末端側ドメインは相同性がほとんど認められない が, C 末端側ドメインには相同性の高い領域が存在してお り，セリンプロテアーゼ特有の catalytic triad も含まれる.

(田辺製薬株式会社 医薬化学研究所 平松 元)

\section{GLP-1}

\section{Glucagon-Like Peptide-1}

Glucagon-like peptide-1 とは, 1 本鎖のポリペプチド からなる消化管由来インスリン分泌刺激因子 (インクレ チン)の1つである. 本ぺプチドは, 食物䝮取の刺激によ り小腸の L 細胞においてグルカゴンを含む不活性型の前 駆体ペプチド（プログルカゴン）として生合成される。 そ の後, プロセッシングを受けることによって活性型の GLP-1 (7-36) NH $\mathrm{N}_{2}$ または GLP-1 (7-37) となり消化管から分 泌される. 本ぺプチドは, インシュリンの分泌促進に加え て，インスリン生合成の充進やグルカゴン分泌抑制等の 作用が報告されている.

（田辺製薬株式会社 医薬化学研究所 平松 元）

\section{ヒストン}

\section{Histone}

真核生物の核内に存在して, 染色体DNA にイオン的な 相互作用で強く結合している一群の塩基性タンパク質. DNA とヒストンの複合体の全体はクロマチンと呼ばれ， そこには 5 種類のヒストン [H1 (分子量 22,000), H2A (分 子量 13,700), H2B (分子量 13,700), H3 (分子量 15,700), H4 (分子量 11,200)] が存在している. クロマチン中には, $(\mathrm{H} 3)_{2}(\mathrm{H} 4)_{2}$ の四量体 1つと $(\mathrm{H} 2 \mathrm{~A}-\mathrm{H} 2 \mathrm{~B})$ の二量体 2 つから 成るヒストン八量体に約 150 塩基対の DNA が巻きついた ヌクレオソームコア粒子が繰り返し存在し，ヒストン $\mathrm{H} 1$ の一部が結合したリンカーDNA（約 50 塩基対）によって
結び付けられている.ヒストン八量体を形成している4種 類のヒストン (H2A, H2B, H3，H4）の N 末端領域は決ま った立体構造をとらないでヌクレオソームコア粒子から 突き出ているため, 特定部位のアミノ酸残基がアセチル 化，メチル化，リン酸化，ユビキチン化などの化学修飾を 受ける.このような化学修飾は特定の制御因子によって認 識され,クロマチンの構造変換を引き起こして遺伝子発現 を制御しているので,このような特異的な部位の化学修飾 の組み合わせが暗号 (コード)を構成するというヒストン コード説が提唱されている.

(横浜市立大学大学院国際総合科学研究科 佐藤

\section{非単純液体金属 Non-Simple Liquid Metals}

単純液体金属は, 液体金属の中で, 例えば液体アルカリ 金属のように，その原子配列について球形の金属玉を乱 雑に並べたような剛体球モデルで説明できるものをいう. したがって, 原子同士の相互作用はある原子半径での斥力 が主で, 引力や相互作用の方向性を特別に考慮しなくても 十分にその原子配列が再現できる. 特に構造因子 $S(Q)$ の 第 1 極大は，非常に対称性の良い形状をしており，このこ とによって単純であると判断されている。しかしながら， $S(Q)$ の第 1 極大が非対称性である液体金属は数多くあり, $\mathrm{Si}, \mathrm{Ge}, \mathrm{Ga}, \mathrm{Te}$ などはその極端な例である. その原因につ いては古くから多くの議論があり，液体金属であっても伝 導電子を介在した金属結合だけでなく, 方向性をもつ引力 である共有結合が存在すると推測するという意見が強い が, その実験的な証拠はなかった。

(広島工業大学・第三世代放射光利用研究推進センター 細川伸也)

\section{高エネルギー分解能 X 線非弾性散乱法 High Energy-Resolution Inelastic X-ray Scattering}

第三世代放射光源と呼ばれる，大型で強度が強く，しか も指向性の良い放射光源の出現によって近年初めて可能 となった物質のダイナミクスを研究する手段である. 現 在, ESRF, APS, SPring-8で合計4つのビームラインがあ る. 主として, $\mathrm{Si}$ 単結晶による後方散乱によって, 数 $\mathrm{meV}$ の高エネルギー分解能が得られており, 中性子線非弾性散 乱法では得られなかった非結晶物質の協調励起状態 (フォ ノン励起) や, 強相関物質の電子励起状態の研究に多くの 成果が得られている. 分解能という点ではまだ中性子線非 弾性散乱法に及ばないが, 物質のダイナミクスの研究に欠 かすことのできない実験手段となりつつある.

(広島工業大学・第三世代放射光利用研究推進センター 細川伸也) 